\title{
Sciendo
}

DOI: $10.2478 /$ lpts-2018-0033

\section{HEAT COST ALLOCATION IN MULTI-APARTMENT BUILDINGS: A LITERATURE REVIEW}

\author{
M. Laicāns ${ }^{1}$, I. Puķīte ${ }^{1}$, I. Geipele ${ }^{1}$, N. Zeltinss ${ }^{2}$ A. Greḳis ${ }^{1}$ \\ ${ }^{1}$ Riga Technical University, \\ Institute of Civil Engineering and Real Estate Economics, \\ 6-210 Kalnciema Str., Riga, LV-1048, LATVIA \\ E-mail: iveta.pukite@rtu.lv \\ ${ }^{2}$ Institute of Physical Energetics \\ 11 Krivu Str., Riga, LV-1006, LATVIA
}

Literature review aims at examining various scientific articles on the accounting methods of individual heat consumption and heat cost allocation.

Nowadays, accounting methods of heat consumption and heat cost allocation in multi-apartment buildings are a topical issue. Heat and water supply is one of the key services provided to residential buildings and their residents. Residents appreciate solutions that allow them consume as much heat as they need and are able to pay, but on condition that the calculation methodology is understandable and easy to perceive.

Directive 2010/31/EU on the Energy Performance of Buildings adopted by the European Parliament and the Council (Directive 2010/31/EU of the European Parliament and of the Council, 2010) stipulates that owners or tenants of buildings shall be provided with the information on energy efficiency measures, their goals and objectives, cost effective ways to improve the energy performance of a particular building and, where appropriate, in the case of available financial instruments to improve the energy performance of a particular building.

The aim of the research is to perform literature analysis using topical articles on the accounting methods of individual heat consumption and heat cost allocation, which are published in the Web of Science and Scopus scientific databases, by analysing and comparing the published results.

Keywords: distribution of heat consumption, heat cost allocators, heat energy accounting, individual heat metering

\section{INTRODUCTION}

Directive 2012/27/EU of the European Parliament and of the Council (EPC) stipulates that "In multi-apartment and multi-purpose buildings with a central heat- 
ing/cooling source or supplied from a district heating network or from a central source serving multiple buildings, individual consumption meters shall also be installed by 31 December 2016 to measure the consumption of heat or cooling or hot water for each unit where technically feasible and cost-efficient. Where the use of individual meters is not technically feasible or not cost-efficient, to measure heating, individual heat cost allocators shall be used for measuring heat consumption at each radiator, unless it is shown by the Member State in question that the installation of such heat cost allocators would not be cost-efficient. In those cases, alternative cost-efficient methods of heat consumption measurement may be considered." (EPC Directive 2012/27/EU, 2012).

Several studies refer to EPC Directive 2012/27/EU on the Energy Performance of Buildings (EPC 2012/27/EU, 2012), which seeks to ensure, to the extent technically feasible, cost-efficient and proportionate to the potential energy savings, that end users of central heating and of domestic hot water at a competitive cost would be provided with individual meters that accurately measure the actual energy consumption of the end user and provide information on actual usage time, envisaging bills free-of-charge that would promote the efficient use of heat and increase consumption efficiency in the sector of residential buildings by mentioning heat meters as effective tools to increase energy efficiency without compromising comfort and setting mandatory installation of such devices by 31 December 2016 in all multi-apartment buildings with a central heating system (Celenza, 2015) (Grasmanis, 2015), (Siggelsten, 2013), (Siggelsten, 2014), (Wang, 2015). In publications, one option is to install energy meters on the radiator surface to measure the amount of consumed heat, which is supplied to the apartment (Cholewa, 2015). In Italy, a number of laws confirm the mandatory installation of temperature control and heat energy measurement systems in significantly renovated buildings, and in new buildings they must be installed in each flat without exception (Celenza, 2015), as well as the laws determine the maximum allowable error in heat distribution systems and devices, which must not exceed $\pm 5 \%$ (Ficco, 2016).

Residents of multi-apartment buildings have different comfort temperatures; therefore, it should be noted that there is a possibility to regulate heat supply to their apartments during the heating season, thus also paying according to their needs and possibilities, where the main criterion is not the heated area, but the actually consumed amount of energy.

The aim of the research is to perform a literature analysis of the accounting methods of individual heat consumption and heat cost allocation. Within the framework of the research, the authors analyse various scientific articles, by clarifying the opinions of scientists and evaluating research results.

To achieve the aim of the research, the following tasks have been set: 1) to select and analyse scientific articles on the subject under study; 2) to identify the main indicators characterising heat cost calculation and allocation in multi-apartment residential buildings; 3 ) to find out calculation methods of heat consumption; 4) to determine the role of heat cost calculation and allocation in multi-apartment residential buildings; 5) to draw conclusions.

The subject of the research is heat cost allocation, the object of the research multi-apartment residential buildings. 
In the course of literature analysis, the authors have used topical articles of the Web of Science and Scopus scientific databases, which were published in the period from 2006 to 2016.

\section{HEAT ENERGY ACCOUNTING AND DISTRIBUTION}

The heat consumption accounting system at the building level records the total heat consumption in the building, and the heat cost allocation method is used to divide the total cost of heat among the apartments. Finnish researchers point out that due to the fact that the indoor temperatures of the multi-apartment buildings are generally not equal, static heat transfer between apartments cannot be avoided. Therefore, in order to measure the fair heat consumption of each apartment, the charging system should be able to determine the static heat transfer, preferably without the real measurement method (Pakanen, 2006).

An individual measuring method in multi-apartment buildings often focuses on the consumption of heat in one room or a group of premises (in an apartment). The principle of the method is that meters determine how the overall heat energy costs are divided between the flats, and these systems are called heat cost allocation systems. In some countries, the system for determining the individual heat consumption has been strengthened by law. The European Commission (EC) recommends that all Member States apply this principle. This regulation has created a range of technical solutions and a set of commercial measuring products (Celenza, 2015), (Liu, 2012).

The heat cost distributor or allocator is an electronic device that determines the proportionality of the heat produced by each radiator in the apartment. These allocators can be installed practically on all types of radiators, both steel panel and sectional radiators. They can be applied to both single-pipe and dual-pipe systems. Heat cost calculation is performed by dividing the total heat costs by allocator measurements. Remote data collection systems are used for data collection and compilation.

Apart from the differences in technical solutions, there are various ways as how to address energy transfer between different apartments or premises with the subsequent cost sharing. Some fee-sharing systems use specific factors to adjust the cost of the calculation period, which is most often one calendar month, according to the location of the apartment in the building, while other methods use project data on static heat transfer to determine heat transfer between apartments. However, all currently available methods only produce rough results, and this problem is known to heat consumers. Finnish researchers clearly indicate that a heat consumption measurement system that collects only consumption data cannot provide a quick and easy way to determine the real heat transfer between apartments and cannot evaluate information about materials, furniture, period and frequency of residence, and the amount of internal heat in each apartment, specifying that the ventilation differs in each apartment depending on the air leakage and the location of the apartment (Pakanen, 2006).

The research concludes that the calculation of heat consumption costs using incomplete information will lead to significant calculation errors. If heating costs 
are not adjusted to each apartment individually, the results of the cost calculation method may approach the model according to which residents pay a steady fee for heating an apartment based on the energy consumption per square metre that does not encourage citizens to take any initiatives to reduce the demand for heating in the apartment and residents can just reduce the room temperature by opening windows or doors (Kavgic, 2012).

\section{DISCUSSION AND RESULTS}

Heating bills issued by heat energy suppliers to residents of multi-apartment residential buildings are based on the readings of heat meters. The boundary of the regulated public service is the introduction of the heat pipe in the building where the heat meter is located, according to which the amount of heat supplied is determined and the payments for the heat energy supplied to the whole building are settled (EUR/MWh). Further calculations are carried out by the manager of a multiapartment residential building, by dividing the fee for the heat energy supplied, thus forming a charge for heating the area of $1 \mathrm{~m}^{2}$.

Individual heat accounting (heating and hot water) is a very important tool for promoting the use of heat energy in multi-apartment residential buildings with a central heating system. The detailed availability of heat consumption data increases the ability of consumers to identify inefficient energy consumption and make their consumption strategy more dynamic (Celenza, 2015).

An assessment of the distribution of heat energy between engineering systems is of importance in multi-apartment residential buildings with the required heat energy consumption for heating, hot water heating and circulation purposes. The heat consumption required for the heating of hot water is determined constant throughout the year. In multi-apartment residential buildings, the amount of heat required for hot water heating purposes could be about $25 \%$ of the total annual consumption of heat energy (or 20 to $25 \mathrm{kWh} / \mathrm{m}^{2}$ per year) for multi-apartment residential buildings with low thermal resistance, which increases in buildings with higher heat resistance. According to the research data, in multi-apartment buildings in Riga, one person consumes 41 liters of hot water at a temperature of $+50-55^{\circ} \mathrm{C}$ per day (Grasmanis, 2013).

Another study, based on measurements from 182 Finnish apartments with 379 residents, confirms that the average consumption of hot water is 43 liters per person per day (see Fig. 1.1) in apartments without individual hot water meters and 35 liters per person per day with individual hot water meters in apartments (Ahmed, 2015).

Chinese researchers Liu et al. refer to the methods already used in the country and only this study uses the calculation methods of heat consumption (see Fig. 1), which are not used in the country but have been successfully adopted in Europe and used in many European countries.

Ziemele et al. propose an algorithm for determining the cost of heat consumption in multi-apartment residential buildings (see Fig. 2). The study indicates that, first of all, the total heat energy consumption in a multi-apartment residential building is specified in Module 1. Second, in the modeling process of calculation it is 
necessary to obtain the total amount of heat consumed for heating purposes (Module 2). Each apartment needs different amount of heat in order to ensure comfort conditions; therefore, it is necessary to introduce additional criteria for the assessment of heat consumption in order to prevent the unfair allocation of heat costs. These criteria are taken into account in Module 3, using certain assumptions (Module 4), determining the heat cost for each apartment in accordance with the method of heat cost allocation (Ziemele, 2015).

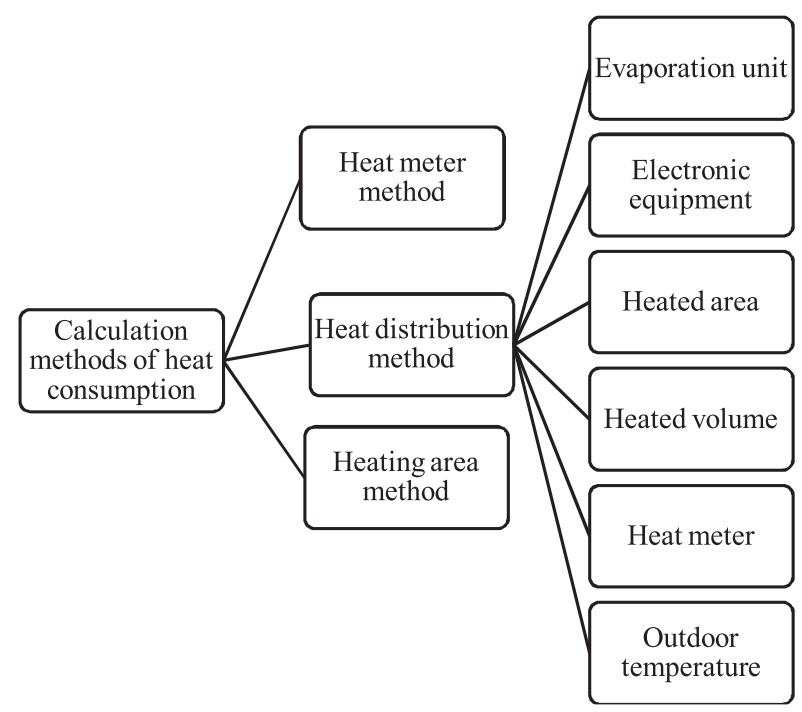

Fig. 1. Calculation methods of heat energy consumption in China (Liu, 2012).
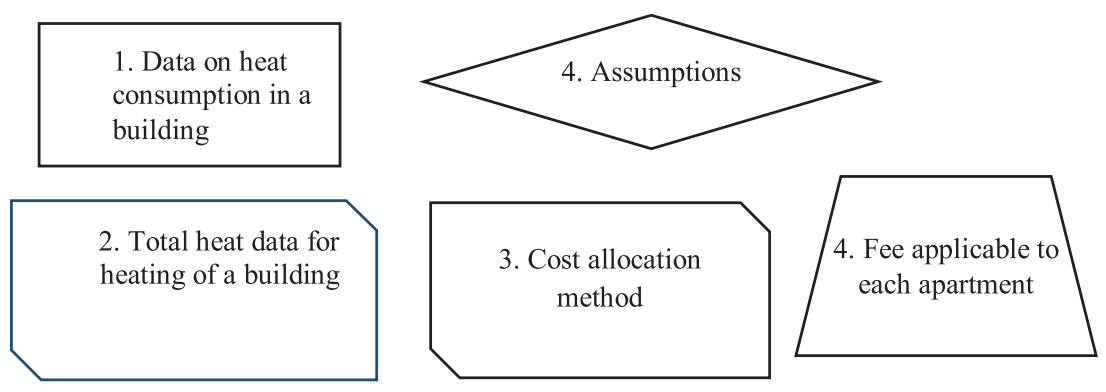

Fig. 2. Calculation of fee for heat energy consumed (Ziemele, 2015).

Studies in Germany have shown a $10 \%-40 \%$ decrease in heat consumption if the apartments are equipped with individual heat meters. The need to introduce individual energy and other resource meters can be observed since the 1920s, when central heating systems began to be used in major European cities. Kupler, for the first time in his studies, mentioned the existence of such meters in 1929. Liu points out that the calculation of heat cost allocation is mainly based on a heated area with two main types of heat consumption billing options - basic consumption at the level 
of the entire building and consumption at the apartment level, concluding that heating costs in Europe are calculated at two stages: the total heat consumption of the building and consumption of each apartment as it is in Germany. Insulated buildings with mechanical ventilation and the ability to control indoor temperatures in Finland make energy savings economically less advantageous compared to investments by installing individual heat meters (Liu, 2015).

Calculating heating costs by applying the average room temperature or temperature of a group of premises in each household, the initial financial contribution and regular management costs are the same as the installation of heat distributors (allocators), only in case of average temperature consumers would be able to open the windows by deliberately lowering heating costs and the goal of the efficient use of heat would not be achieved, as a result of which this method is prohibited in Germany (Liu, 2015).

The individual heat meter determines heat consumption by calculating the circulation rate of heat flow and the difference between the temperatures of inward flow and outward flow (see Fig. 1.4), thus an overall uncertainty in the estimation of heat consumption can be around $2.9 \%-8.9 \%$. In most cases, manufacturers specify an uncertainty of the heat meter of $4.4 \%$ (Celenza, 2015).

Heat meters measure heat consumption over a certain period of time, multiplying by the temperature difference of the heat carrier, entering the closed apartment heating system and escaping from the heating system of the apartment. Heat meters consist of a flow sensor (V), a pair of temperature sensors (Tie, Tiz) and a calculator with a built-in processor and software for measuring heat consumption (Ficco, 2016).

An individual heat meter installed near the radiator can measure the amount of heat supplied to the apartment, but if there is more than one radiator in the apartment, this can be a very economically ineffective method and as an alternative a heat meter is installed on each radiator; however, the study clearly demonstrates errors in both methods in the case of an apartment building with a centralised mechanical ventilation system with a heat recovery function (Siggelsten, 2013).

For individual heat consumption accounting, heat cost allocators can be used in heating systems that are supplied with heaters, and heat cost dividers (alcocators) are installed on each heat source unit together with a thermostatic valve, and studies performed demonstrate an overall uncertainty of an average of $9.2 \%$. Rarely, uncertainty of allocators is less than $3.5 \%$ and at worst, it can reach $40.5 \%$ (Celenza, 2015).

Individual heat cost allocators are not measuring equipment and do not actually show actual heat consumption in a particular apartment, but refer to separate calculation procedures designed to allocate energy costs between different apartments in multi-apartment buildings with central heating (Cholewa, 2015).

The individual heat metering method with allocators is mostly applied to dwellings in Europe (Finland, Germany, Austria etc.) (Huebner, 2013), because in these countries the thermal insulation properties of building envelopes are generally good; hence, the difference in the heating fee caused by different locations of apartments in the building has less impact on the amount of the fee and the heating costs 
in general for the apartment make up a small percentage of the total income of the person, so the difference in the heeting fee is insignificant. The total cost of heating, including both heating and hot water, accounts for only $2 \%-5 \%$ of the total income of the population in the developed countries (Liu, 2015).

Electronic individual heat cost allocators can effectively control the opening of windows as they also measure room temperature and their accuracy is higher than that of evaporative heat cost allocators, but also costs are higher. It should also be noted that electronic meters can only be installed on certain types of radiators, the availability of installation is similar to evaporators, and the quality depends on the installation and accuracy of the calculation algorithm (Liu, 2015).

The method of measurement with heat cost allocators should also take into account the heat loss through the building envelope and heat gain, the heat flow from the riser pipes; it is necessary to recalculate the radiator assessment factor and the heat transfer between the apartments, as well as the fixed and variable proportion of the heat content each month, while the fixed consumption consists of the heat gain from uncovered heating network pipes in apartments and heat consumption in common areas (Ziemele, 2015).

The heat cost allocation method, which relatively solves the problem of heat transfer between adjacent apartments, determines the value of the temperature of each thermostat that is sent to a central processor, which theoretically means that the residents pay for the desired indoor temperature and it does not matter whether the heat comes from radiators or from adjacent apartments, but researchers point to the negative aspects of this method, because this method ignores the effect of window opening as well as the factor of solar radiation and internal heat gain (Fabi, 2012).

As an alternative to the above-mentioned methods, Liu et al. recommend an "on-off" method based on the operating time ratio of the thermostat valve, which will not require any correction in terms of the location of an apartment, because the heating system must be provided with heaters according to the location of an apartment in the multi-apartment residential building - the more exterior walls in the apartment, the larger radiators; however, this method does not take into account the heat transfer between adjacent apartments and the effect of the ventilation system on the total heat energy consumption balance (Liu, 2012).

In his research, Siggelsten mentions several studies that found out that the heat transfer between adjacent apartments could lead to an unfair distribution of heat costs and, in his research, he provides an example of unfair heat cost allocation in an existing multi-apartment building, for example, in an apartment of the building with almost no heat cost allocators during the heating season, which is impossible in Swedish climatic conditions. The research also indicates that 6 out of 16 apartments are overcharged and 7 out of 16 apartments pay less; therefore, in his research, he proposes making adjustments to the measurements provided by heat cost allocators, by comparing internal heat gain with the electricity consumption in an apartment, but he notes that such a calculation method only complicates the acquisition of data for the calculation model (Siggelsten, 2014).

Multi-apartment residential buildings comprise a significant sector of the heat energy market as the recipient of services and the end consumer. Consequently, by 
introducing individual heat cost allocators in separate apartments, it is possible to reduce the total heat energy consumption of a residential building. In order to achieve this goal, it is necessary to introduce a fair calculation of the heat cost allocation, taking into account the various methods used in practice and the correction coefficients.

\section{CONCLUSIONS}

1. Latvian researchers note that different results of hot water consumption provided in various studies can be explained by the temperature of hot water that differs in the collection point, in the case of higher temperatures, hot water consumption will be lower. Studies confirm that hot water consumption is not attributed to the behaviour and habits of residents of multi-apartment residential building.

2. Heat energy losses with hot water circulation lines in multi-apartment residential building are significant, and heat energy consumption with a high degree of precision can be calculated in the summer. In the heating period, correction is not applied to calculations of losses with hot water circulation lines in the summer. However, to determine the fee for the heat energy necessary for the circulation of hot water, several calculation methods are used, where the cost of heat energy consumption is divided by: the area of the apartment $\left(\mathrm{MWh} / \mathrm{m}^{2}\right)$; number of apartments (MWh/flat); number of residents (MWh/person).

3. Accurate measurement of individual heat consumption is a complicated process because the energy consumed by the upper corner apartments is two to three times higher than the energy consumed by apartments located in another part of the building and, besides, heating costs can increase by $20 \%-30 \%$ if the adjacent apartments are not heated and it is considered that the existing measurement methods cannot effectively solve these two problems, so they are not relevant.

4. The installation of heat cost allocators is not classified as a method for reducing energy consumption, but it allows heat consumers to freely choose the desired comfort indoor temperature for which they are willing to pay. Therefore, it is very difficult to accurately calculate the economic benefits of installing heat cost allocators, since it is not possible to accurately predict heat savings.

5. Researchers indicate that the introduction of heat cost allocation is a tool that can be used to ensure that the consumers pay only for the heat supplied to them and that every resident can follow the heat consumption and this increases the motivation of the population to regulate the indoor temperature by reducing the heat consumption, but in this case the heat gain from uncovered heat riser pipes in apartments varies from $22.5 \%$ to $4.1 \%$.

\section{REFERENCES}

1. Ahmed, K., Pylsy, P., \& Kurnitski, J. (2015). Monthly domestic hot water profiles for energy calculation in Finnish apartment buildings. Energy and Buildings, 97, 77-85.

2. Celenza, L., Dell'Isola, M., Ficco, G., Palella, B.I., \& Riccio, G. (2015). Heat accounting in historical buildings. Energy and Buildings, 95, 47-56. 
3. Cholewa, T., \& Siuta-Olcha, A. (2015). Long term experimental evaluation of the influence of heat cost allocators on energy consumption in a multifamily building. Energy and Buildings, 104, 122-130.

4. EPC Directive 2010/31/EU. Directive of the European Parliament and of the Council. On the Energy Performance of Buildings. [Online] 19 May 2010. [Accessed: 10 March 2017] http://eurlex.europa.eu/LexUriServ/LexUriServ.do?uri=OJ:L:2010:153:0013:003 5:lv:PDF.

5. EPC Directive 2012/27/EU. Directive of the European Parliament and of the Council. On the Energy Performance of Buildings. [Online] 25 October 2012. [Accessed: 12 March 2017] http://eurlex.europa.eu/LexUriServ/LexUriServ.do?uri=OJ:L:2012:315:0 001:0056:LV:PD.

6. Fabi, V., Andersen, R.V., Corgnati, S., \& Olesen, B.W. (2015). Occupants' window opening behaviour: A literature review of factors influencing occupant behaviour and models. Building and Environment, 58, 188-198.

7. Ficco, G., Celenza, L., Dell'Isola, M., \& Vigo, P. (2016). Experimental comparison of residential heat accounting systems at critical conditions. Energy and Buildings, 130, 477-487.

8. Grasmanis, D., Grekis, A., \& Talcis, N. (2013). Heat consumption assessment of the domestic hot water systems in the apartment buildings. Construction Science, 14, 38-43.

9. Grasmanis, D., Talcis, N., \& Greḳis, A. (2015). Buildings, Heat Consumption Assessment of the Domestic Hot Water Systems in the Apartment. Construction Science, 167176.

10. Huebner, G.M., Cooper, J., \& Jones, K. (2013). Domestic energy consumption - What role do comfort, habit, and knowledge about the heating system play? Energy and Buildings, 66, 626-636.

11. Kavgic, M., Summerfield, A., Mumovic, D., Stevanovic, Z.M., Turanjanin, V., \& Stevanovic, Z.Z. (2012). Characteristics of indoor temperatures over winter for Belgrade urban dwellings: Indications of thermal comfort and space heating energy demand. Energy and Buildings, 47, 506-514.

12. Liu, L. (2015). Major issues and solutions in the management system of space heating system in North China. Renewable and Sustainable Energy Reviews, 130, 221-231.

13. Liu, L., Fu, L., \& Jiang, Y. (2012). A new "wireless on-off control” technique for adjusting and metering household heat in district heating system. Applied Thermal Engineering, 36, 202-209.

14. Pakanen, J., \& Karjalainen, S. (2006). Estimating static heat flows in buildings for energy allocation systems. Energy and Buildings, 38(9), 1044-1052.

15. Siggelsten, S. (2014). Reallocation of heating costs due to heat transfer between adjacent apartaments. Energy and Buildings, 75, 256-263.

16. Siggelsten, S., \& Olander, S. (2013). Individual metering and charging of heat and hot water in Swedish housing cooperatives. Energy Policy, 61, 874-880.

17. Wang, J., \& Li, D. (2015). Economic and technical analysis of several heat metering modes: A case study from Beijing, China. Procedia Engineering, 121, 1037-1043.

18. Ziemele, J., Pakere, I., Blumberga, D., \& Zogla, G. (2015). Economy of heat cost allocation in apartment buildings. Energy Procedia, 72, 87-94. 


\section{SILTUMA MAKSU SADALĪŠANA DAUDZDZĪVOKḶU MĀJĀS}

M. Laicāns, I. Puķīte, I. Geipele, N. Zeltiņš, A. Greķis

Kopsavilkums

Lieteratūras apskatā tiks izvērtēti dažādi zinātniski raksti par individuālās siltumenerǵijas patēriņa uzskaites un maksas daḷas noteikšanas metodēm.

Mūsdienās siltumenerğijas patēriņa uzskaites un maksas daḷas noteikšanas metodes daudzdzīvokḷu ēkās ir aktuāla problēma. Siltuma un ūdens nodrošināšana ir viens no pamatpakalpojumiem, kas tiek nodorošināts dzīvojamām mājām un tajos dzīvojošām personām. Iedz̄ivotāji augsti novērtē risinājumus, kas lauj siltumenerğiju patērēt tik, cik katrs vēlas un spēj apmaksāt, bet ar nosacījumu, ka aprēķina metodika ir saprotama un viegli uztverama.

EPP direktīva 2010/31/ES par ēku energoefektivitāti, nosaka sniegt informāciju ēku īpašniekiem vai īrniekiem par energoefektivitātes pasākumiem, to nolūkiem un mērķiem, par rentabliem veidiem, kā uzlabot attiecīgo ēku energoefektivitāti un, vajadzības gadījumā, par pieejamiem finanšu instrumentiem, lai uzlabotu attiecīgās ēkas energoefektivitāti.

Pētījuma mērḳis ir veikt literatūras analīzi par individuālās siltumenerğijas patēriņa uzskaites un maksas daļas noteikšanas metodēm. Pētījuma priekšmets ir siltuma maksas sadalīšana, pētījuma objekts - daudzdzīvokḷu dzīvojamās mājas.

Literatūras analīzes gaitā tika izmantoti aktuālie raksti zinātniskajās datubāzēs Web of Science un Scopus, kuri ir publicēti laika posmā no 2006.gada $\overline{1} d z 2016$. gadam.

$$
\text { 18.07.2018. }
$$

